\title{
Mining in Turkey
}

\author{
Semra Bilgic* \\ Department of Chemistry, Ankara University, Ankara, Turkey
}

Submission: October 23, 2020; Published: December 15, 2020

*Corresponding author: Semra Bilgic, Department of Chemistry, Ankara University, Ankara, Turkey

Keywords: Boron; Metals; Mining industry; Natural stones

\section{Opinion}

Turkey is a country rich diversity of underground resources. Textronic and complex geological structure of Turkey allows the availability of a wide variety of mineral deposits. Today, approximately 90 types of mines are produced in the world. In Turkey, production is made of approximately 60 types of mines. Turkey, in 132 countries across the world, as the total value of mineral production in the $2^{\text {nd }}$ ranks, in terms of the diversity of minerals is ranked $10^{\text {th }}$. Turkey is a rich country in terms of particularly industrial raw materials, some metallic minerals such as lignite, and geothermal sources of energy. $2.5 \%$ of world reserves of industrial raw materials, $1 \%$ of coal reserves, $0.8 \%$ of the geothermal potential, and $0.4 \%$ of the metallic mineral reserves are in Turkey.

First among which Turkey is rich in minerals, are boron minerals with $74 \%$ of world reserves. However, except for a few reserves on a global scale mines in Turkey are limited. World production of and trade in mining and mineral 13 of the 90 types, with failing to detect the presence of economies of scale, in 50 kinds of minerals, partly Turkey has sufficient resources. The reserves and qualities of 27 mines and minerals are insufficient for economical mining. Despite being a country rich in mineral resources and minerals, Turkey is among the countries selfsufficient. Boron and boron compounds are at the top of the rich mineral resources in Turkey. In addition, barite, gypsum, meerschaum, marble, diatomite, perlite, strontium salts, sepiolite, limestone, pumice, sodium sulphate, xeolite, quartz-quartzite, lignite, feldspar, rock salt, iron, silica sand, golden bentonite, asbestos, calcite and emery stone can be mentioned. However, kaolin, kaolin carbon dioxide, chromium, molybdenum-bauxite, mercury-antimony, thorium, silver, tungsten, sand-gravel and brick soil can be counted. Copper, manganese, lead, aluminum, coal, zinc, zircon, titanium, iron, sulfur, nickel and ash minerals are insufficient. Therefore, Turkey, paying about $\$ 25$ billion annually, imports many minerals and metals like coal, iron ore, copper, lead, and zinc.

Boron mine is used as leather colorant, insecticides, electronic refining, cosmetics, medicine, cement, corrosion inhibitors, adhesives, disinfectants, catalysts, nylon, fertilizers, fire resistant materials, nuclear fuel technology, medicine, textiles, glass fibers. Also, boron silicate is used as antiseptics, medicine, industrial glasses, boric acid production, photography, paint, textile, metallurgical applications, fire resistant material, soap in detergent industry, enamel in coating industry and glass industry. This mine, widely as a raw material, is among the industrial mines that can be strategically used in all areas of human life. Boron, which has an important place in space technology in the world, is indisputably important in living and reaching the information and electronic age. The use of boron element in vehicles is the subject of many studies in recent years. In Turkey, which ranked first in the world in terms of the element boron, within the scope of transforming boron into a value added and strategic product, a few important facilities are under construction and are expected to be put into service in a short time.

The mining industry is the most difficult and risky business in the world, which is characterized by its nature and therefore requires knowledge, expertise and continuous experience. For these reasons, prospecting in Turkey for many years has been neglected. The most important problem in the mining industry is mining accidents, often resulting in catastrophes. Turkey is at the forefront of mining accidents. When mine accidents in Turkey are investigated, it is seen that the incident has many reasons such as technical, economic, educational, planning and audit problems. This is because the necessary measures for occupational health and safety are not taken sufficiently in Turkey. Education has 
great importance in this sector. There are many state and private universities in Turkey. However, 19 of these universities have mining engineering departments, and the quality of education is very low. The number of mining engineering departments in Turkey is too high, and the resources allocated to this part of the budget is inadequate. In addition to these negativities, they also have positive contributions to the country's economy. Turkey, with production of raw materials to other sectors, contribute to the formation of a value close to $\$ 40$ billion. The mining industry closed 2018 with exports of $\$ 4.3$ billion. 80 of the 90 mineral species production in the world is located in Turkey. There are also 150 different types of natural stones. Turkish mines are used in 197 countries around the world. 